\title{
Deletion of Interleukin-6 Signal Transducer gp 130 in Small Sensory Neurons Attenuates Mechanonociception and Down-Regulates TRPA1 Expression
}

\author{
Philipp Malsch, ${ }^{1}$ Manfred Andratsch, ${ }^{1}$ Christian Vogl, ${ }^{1}$ Andrea S. Link, ${ }^{2}$ Christian Alzheimer, ${ }^{2}$ Stuart M. Brierley, ${ }^{3,4,5}$ \\ Patrick A. Hughes, ${ }^{5,6}$ and Michaela Kress ${ }^{1}$ \\ ${ }^{1}$ Department of Physiology and Medical Physics, Division of Physiology, Medical University of Innsbruck, A-6020 Innsbruck, Austria, ${ }^{2}$ Institute of \\ Physiology and Pathophysiology, Friedrich-Alexander University Erlangen-Nuremberg, 91054 Erlangen, Germany, ${ }^{3}$ Nerve-Gut Research Laboratory, \\ Discipline of Medicine, Faculty of Health Sciences, University of Adelaide, Adelaide, South Australia, Australia 5000, ${ }^{4}$ Department of Gastroenterology and \\ Hepatology, Royal Adelaide Hospital, Adelaide, South Australia, Australia 5000, ${ }^{5}$ Discipline of Physiology, Faculty of Health Sciences, University of \\ Adelaide, Adelaide, South Australia, Australia 5000, and 'Leukocyte Biology Department, Women's and Children's Health Research Institute, North \\ Adelaide, Australia 5006
}

Glycoprotein 130 (gp130) is the signal transducing receptor subunit for cytokines of the interleukin-6 (IL-6) family, and it is expressed in a multitude of cell types of the immune and nervous system. IL-6-like cytokines are not only key regulators of innate immunity and inflammation but are also essential factors for the differentiation and development of the somatosensory system. Mice with a null mutation of gp130 in primary nociceptive afferents $\left(S N S-g p 130^{-/-}\right)$are largely protected from hypersensitivity to mechanical stimuli in mouse models of pathological pain. Therefore, we set out to investigate how neuronal gp130 regulates mechanonociception. SNS$g p 130^{-1-}$ mice revealed reduced mechanosensitivity to high mechanical forces in the von Frey assay in vivo, and this was associated with a reduced sensitivity of nociceptive primary afferents in vitro. Together with these findings, transient receptor potential ankyrin 1 (TRPA1) mRNA expression was significantly reduced in DRG from SNS-gp130 ${ }^{-/-}$mice. This was also reflected by a reduced number of neurons responding with calcium transients to TRPA1 agonists in primary DRG cultures. Downregulation of Trpa1 expression was predominantly discovered in nonpeptidergic neurons, with the deficit becoming evident during stages of early postnatal development. Regulation of Trpa1 mRNA expression levels downstream of gp130 involved the classical Janus kinase family-signal transducer and activator of transcription pathway. Our results closely link proinflammatory cytokines to the expression of TRPA1, both of which have been shown to contribute to hypersensitive pain states. We suggest that gp130 has an essential role in mechanonociception and in the regulation of TRPA1 expression.

Key words: cytokine; Il-6 signal transducer; JAK/STAT signaling; mechanonociceptor; mechanotransduction; pain

\section{Introduction}

Neuropoietic cytokines of the interleukin-6 (IL-6) family are essential regulators of innate immunity and nerve regeneration.

\footnotetext{
Received Dec. 10, 2013; revised May 19, 2014; accepted May 22, 2014.

Author contributions: P.M. and M.K. designed research; P.M., M.A., C.V., and A.S.L. performed research; P.M. analyzed data; P.M., M.A., C.V., A.S.L., C.A., S.M.B., P.A.H., and M.K. wrote the paper.

This work was supported by the Austrian Research Funding Agency FWF Project Grants 18444-B13 and SPIN-DK W1206-B18 to M.K., S.M.B. is an National Health and Medical Research Council R.D. Wright Biomedical Research Fellow. P.A.H. is supported by an National Health and Medical Research Council Australia Biomedical fellowship. We thank K. Braun, T. Martha, and M. Doblander for expert technical assistance; Dr. Christoph Schwarzer and Dr. Paul Jennings for technical advice; and Dr. Peter Reeh for providing TRPA1 ${ }^{+/+}$and TRPA1 ${ }^{-/-}$mice.

The authors declare no competing financial interests.

This article is freely available online through the J Neurosci Author Open Choice option.

Correspondence should be addressed to Dr. Michaela Kress, Medical University Innsbruck, Department of Physi-

ology and Medical Physics, Division of Physiology, Fritz-Pregl-Str. 3, A-6020 Innsbruck, Austria. E-mail: michaela.kress@i-med.ac.at.

C. Vogl's present address: Inner Ear Lab, Department of Otolaryngology, University of Goettingen Medical Center, 37075 Goettingen, Germany.

DOI:10.1523/JNEUROSCI.5161-13.2014

Copyright $\odot 2014$ the authors $\quad 0270-6474 / 14 / 349845-12 \$ 15.00 / 0$
}

The cytokines act on their target cells via heteromeric receptor complexes that require glycoprotein 130 (gp130) as signal transducer subunit (Heinrich et al., 2003). In addition to IL-6, the family consists of IL-11, IL-27, leukemia inhibitory factor (LIF), ciliary neurotrophic factor (CNTF), oncostatin M (OSM), neuropoietin, cardiotrophin-1, and cardiotrophin-like cytokine (Bauer et al., 2007).

In addition to their role in innate immunity, gp130-targeting cytokines are important survival and differentiation factors. IL-6, CNTF, OSM, and LIF play crucial roles in the brain and in the peripheral nervous system (Murphy et al., 1991, 1993; Thompson et al., 1996; Banner et al., 1998; Nakashima et al., 1999; Zhong et al., 1999). OSM, for example, is essential for the development and survival of a subpopulation of TRPV1/P2X3-positive sensory neurons (Morikawa et al., 2004). However, OSM and IL-6, but not LIF, sensitize nociceptors to heat (Langeslag et al., 2011).

Thermal sensitization occurs as a consequence of fast modulation of the heat and capsaicin-sensitive ion-channel TRPV1, whereas ablation of gp130 in $\mathrm{Na}_{\mathrm{v}} 1.8$-expressing small-diameter 
DRG neurons (SNS-gp $130^{-/-}$) reduces thermal hypersensitivity in models of pathological pain (Obreja et al., 2002, 2005; Andratsch et al., 2009). Furthermore, IL-6 sensitizes nociceptors to noxious mechanical stimuli, and SNS-gp $130^{-/-}$mice are largely protected and recover faster from mechanical hypersensitivity in models of inflammatory, neuropathic, and cancer pain (Brenn et al., 2007; Quarta et al., 2011).

It is generally accepted that the detection of noxious mechanical stimuli (mechanonociception) relies on the presence of mechanically activated ion channels in nociceptive neurons. Differential expression and sensitization of these putative ion channels very likely contribute to the mechanical hypersensitivity associated with chronic pain states. Despite the anticipated importance of such channels, the cellular and molecular mechanisms of mechanonociception are still incompletely understood (Lumpkin and Caterina, 2007; Dubin and Patapoutian, 2010; Delmas and Coste, 2013).

In the present study, we assessed mechanonociception in the SNS-gp $130^{-/-}$mouse model in vivo and with an in vitro skinnerve preparation. Moreover, a genome-wide mRNA expression profiling assay was used to screen for differential expression of nociceptor-specific ion-channel mRNA. The expression of candidates was assessed with quantitative TaqMan RT-PCR, ISH of DRG sections, as well as correlative functional assays. Here, we demonstrate that ablation of gp130 reduces the sensitivity of nociceptive fibers to noxious mechanical stimuli and that the presence of gp130 in small DRG neurons is essential for the expression of the TRPA1 ion channel.

\section{Materials and Methods}

Animals. SNS-gp130 $130^{-/-}$and $g p 130^{f l f l}$ mice were generated, bred, and genotyped as described previously (Andratsch et al., 2009). Briefly, $g p 130^{f l f l}$ mice were cross-bred with SNS-Cre mice (Agarwal et al., 2004)

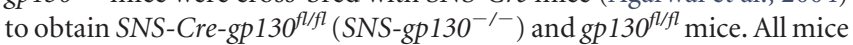
were maintained under specific pathogen free conditions. TRPA1 $1^{-1-}$ mice were a generous gift from Dr. David Corey (Harvard Medical School, Boston) and used as controls where appropriate (Kwan et al., 2006). Unless otherwise stated, animals of either sex and older than 8 weeks were used in all experiments. For postnatal development studies, animals were staged by their date of birth. Day of birth was counted as postnatal day $0(\mathrm{P} 0)$. Behavioral measurements and analyses were performed in awake, unrestrained, age-matched, male mice with an age of $8-16$ weeks by examiners who were blinded to the genotype of the mice. All animal procedures were in accordance with ethical guidelines and animal welfare regulations according to Austrian law and with formal permission of the Austrian BMWF ministry (BMWF-66.011/0051-II/ 10b/2008; BMWF-66.011/0113-II/3b/2010).

Mechanical sensitivity. Mice were placed in a plastic chamber with a wire mesh floor and allowed to habituate for $1 \mathrm{~h}$ before starting the test. The lateral side of the plantar surface of the paw (sural nerve innervation territory) was stimulated by calibrated von Frey monofilaments. Filaments were applied in an ascending force order $(1.4,4,8,16,22.6,32$, and $45.3 \mathrm{mN}$ ), and the frequency of paw withdrawal to 5 stimuli for each monofilament was recorded. The threshold was taken as the lowest force that evoked a brisk withdrawal response to two of five repetitive stimuli. Mechanical sensitivity was assessed on two separate days, and threshold values were averaged per animal. One animal in the SNS-gp $130^{-/-}$group failed to fulfill the threshold criterion and was assigned the highest mechanical force $(45.3 \mathrm{mN})$ as threshold.

Nocifensive behavior. Spontaneous pain-like behavior was monitored after intracutaneous injection of $20 \mu \mathrm{l}$ of $1 \%$ cinnamaldehyde (CA, Sigma) or vehicle (20\% Tween 80 , Sigma) in PBS (PAA) into the hindpaw of $g p 130^{f l f l}$ or $S N S-g p 130^{-/-}$mice. Mice were placed in a plastic chamber and allowed to habituate for at least $1 \mathrm{~h}$ before the experiment. Movies were taken with a Zx1 (Kodak) or an IN-3011 (Instar) camera through the translucent floor of the box so that the hindpaws were visible at all times. Behavioral responses were scored for 5 min after injection. Vehicle controls were injected into the hindpaw contralateral to CA 1 week after the initial treatment, and the mice did not show a response during the analyzed time frame.

Single fiber recordings. An in vitro skin nerve preparation was used to investigate the properties of unmyelinated afferent nerve fibers innervating the skin of the mouse dorsal hindpaw as previously reported (Andratsch et al., 2009; Quarta et al., 2011). The saphenous nerve was dissected with the skin of the dorsal hindpaw attached and mounted in an organ bath "inside-up" to expose the corium side. The preparation was superfused $(15 \mathrm{ml} / \mathrm{min})$ with an oxygen-saturated modified synthetic interstitial fluid solution containing (in $\mathrm{mm}$ ) as follows: $108 \mathrm{NaCl}, 3.48$ $\mathrm{KCl}, 3.5 \mathrm{MgSO}_{4}, 26 \mathrm{NaHCO}_{3}, 1.7 \mathrm{NaH}_{2} \mathrm{PO}_{4}, 2.0 \mathrm{CaCl}_{2}, 9.6$ sodium gluconate, 5.5 glucose, and 7.6 sucrose at a temperature of $31 \pm 1^{\circ} \mathrm{C}$ and pH $7.4 \pm 0.05$. The saphenous nerve was pulled into a separate chamber of the organ bath and placed on a small mirror. Using sharpened watchmakers' forceps, fine filaments were teased from the desheathed nerve and placed on a gold wire recording electrode. Action potentials of single-nerve strands were recorded extracellularly, amplified $(5000 \times)$, filtered (low pass $1 \mathrm{kHz}$, high pass $100 \mathrm{~Hz}$ ), visualized on an oscilloscope, and stored on a PC-type computer with Spike/Spidi software package for offline analysis using a template-matching procedure. The fibers were characterized as unmyelinated (C) according to their conduction velocity $(<2 \mathrm{~m} / \mathrm{s}$, calculated from the latency of unitary action potential to electrical stimulus at receptive field and distance of receptive field to recording electrode) and on the basis of the shape of the action potential. The receptive field of the primary afferent fiber was located by mechanical probing of the skin with a blunt glass rod. Only units with a signalto-noise ratio $>2$ were used for further analysis. Fibers were subject to a standard protocol of adequate mechanical stimuli. The mechanical threshold of each unit was determined with a set of calibrated von Frey monofilaments with uniform tip diameter $1.1 \mathrm{~mm}$ and bending forces ranging from 1 to $362 \mathrm{mN}$. The strength of the finest filament that evoked at least 3 action potentials was defined as activation threshold.

DRG culture. DRG containing the cell bodies of primary afferents were harvested from adult mice as previously published (Andratsch et al., 2009; Camprubí-Robles et al., 2013). After removal of the connective tissue, ganglia were incubated in Liberase Blendzyme $1(9 \mathrm{mg} / 100 \mathrm{ml}$ DMEM, Roche) for 2 times at $30 \mathrm{~min}$. After washing with PBS (PAA), $1 \times$ trypsin-EDTA (Invitrogen) was added for $15 \mathrm{~min}$, and DRG were washed three times with DMEM and once with TNB medium (Biochrom) supplemented with Protein-Lipid-Complex (Biochrom), L-glutamine, penicillin G sodium, and streptomycin sulfate (all from Invitrogen). The DRG were dissociated in TNB medium with a fire-polished Pasteur pipette and centrifuged through a 3.5\% BSA gradient (Sigma) to eliminate non-neuronal cells and debris. The sensory neurons were resuspended, plated on either 6-well or 24-well culture dishes (Nunc) coated with poly-L-lysine/laminin-1 (Sigma), and cultivated in supplemented TNB at $37^{\circ} \mathrm{C}$ in $5 \% \mathrm{CO}_{2}$ for $24 \mathrm{~h}$, unless otherwise indicated. For microfluorimetric calcium measurements, cells were plated on glass-bottom dishes coated with poly-L-lysine/laminin-1 (Sigma) and cultivated for 18-32 h. Exogenous mNGF 2.5S (Alomone Labs, $10 \mu \mathrm{g} / 100 \mathrm{ml}$ TNB medium) was added whenever indicated.

In vitro inhibitor studies. DRG were harvested from spinal segments T1 to L6, and cultures were prepared as described above. Dissociated neurons of one to three $g p 130^{f / f l}$ mice were pooled and subsequently divided into control and inhibitor samples. Inhibitor samples were first pretreated with nontoxic concentrations of Janus kinase family (JAK) inhibitor I $(1 \mu \mathrm{M}$, Calbiochem/Millipore) (Loy et al., 2011) or signal transducer and activator of transcription (STAT) inhibitor Stattic (1.5 $\mu \mathrm{M}$, Sigma) (S. Quarta, Medical University Innsbruck, Austria, personal communication) in TNB medium for $1 \mathrm{~h}$ and then incubated with the same concentration of inhibitor diluted in TNB medium containing exogenous mNGF $2.5 \mathrm{~S}$ for $72 \mathrm{~h}$. Inhibitors were dissolved in DMSO in a maximal final dilution of 1:1000. Control samples received an equal treatment with medium containing the appropriate concentration of vehicle.

Genome-wide mRNA expression profiling assay. DRG explants were prepared as described above. DRG samples of two littermate mice were always pooled, and a total of $10 \mathrm{gp} 130^{f / f l}$ and $10 \mathrm{SNS}-\mathrm{gp} 130^{-/-}$mice 
were divided into five groups per genotype. RNA isolation, cRNA preparation, and microarray measurement with subsequent analysis were performed by IMGM Laboratories using Mouse Genome Survey Microarray V2.0 with the 1700 Chemiluminescent Microarray Analyzer (Applied Biosystems). For genes to be included in the analysis, all five samples of at least one genotype had to obtain a signal-to-noise ratio of $\geq 3$. Functional annotation of the genes was based on the Panther 2.0 database (www.pantherdb.org). All genes that belonged to the Panther_Function "ion channel" or "ligand-gated ion channel" were grouped as "ion channels." Only genes with net fold changes $>1.5$ were considered as differentially expressed between the two genotypes. Student's $t$ test was applied to compare SNS- $g p 130^{-/-}$and $g p 130^{f l / f l}$ groups. The $p$ values were corrected for multiple testing using the algorithm of Benjamini and Hochberg, which is based on a control of the false discovery rate (FDR) (Benjamini and Hochberg, 1995). Microarray data are available in the ArrayExpress database (www.ebi.ac.uk/arrayexpress) under accession number E-MTAB-2584.

$q R T-P C R$. For analysis of mRNA expression levels, total RNA was isolated from murine DRG explants or primary cultures of DRG neurons by using TRI Reagent (Sigma) or peqGOLD TriFast (PeqLab) as previously published (Andratsch et al., 2009). DRG explants were lysed with a Tissue Lyser II (QIAGEN) or manually using plastic pestles. Primary cultures of DRG neurons were directly lysed on the culture dish and subsequently used for RNA extraction. The quantity of RNA was analyzed using a BioPhotometer (Eppendorf) or a Nanodrop 2000 (Thermo Scientific) and, where applicable, RNA quality was verified by gel electrophoresis. Reverse transcription to cDNA was performed using MuLv reverse transcriptase $(2.5 \mathrm{U} / \mu \mathrm{l}$, Applied Biosystems) with random hexamer primers $(10 \mathrm{ng} / \mu \mathrm{l})$, RiboLock $(2 \mathrm{U} / \mu \mathrm{l}), 1 \times$ Taq Buffer (all from Thermo Scientific), $\mathrm{MgCl}_{2}(5 \mathrm{~mm})$, and dNTPs (1 mM, both Fermentas). cDNA samples were analyzed for expression of target genes by quantitative real-time TaqMan PCR using TaqMan 5' nuclease assays (all from Applied Biosystems). With the exception of $18 \mathrm{~S}$ (18S ribosomal RNA, Hs99999901_s1), the following exon spanning assays were used: Mm01352363_m1 (succinate dehydrogenase subunit A, Sdha), Mm00625268_m1 (transient receptor potential ankyrin 1, Trpa1), Mm01246302_m1 (transient receptor potential vanilloid 1, Trpv1), Mm00499025_m1 (transient receptor potential vanilloid 4, Trpv4), and Mm99999915_g1 (glyceraldehyde-3-phosphate dehydrogenase, Gapdh). Reactions were performed in a MicroAmp Fast Optical 96-Well Reaction Plate (Applied Biosystems) using the 7500 Fast Real-Time PCR System (Applied Biosystems) for thermal cycling and real-time fluorescence measurements. The PCR cycle protocol consisted of $10 \mathrm{~min}$ at $95^{\circ} \mathrm{C}$, and 50 two-step cycles of $15 \mathrm{~s} \mathrm{each}$ at $95^{\circ} \mathrm{C}$ and of $1 \mathrm{~min}$ at $60^{\circ}$. Positive and negative controls (no-template controls for RNA extraction, RT-PCR, and TaqMan-qPCR) were included in the experiments. Each sample was run in duplicates or triplicates. Threshold cycle $\left(\mathrm{C}_{\mathrm{T}}\right)$ values were recorded as a measure of initial template concentration. For duplicates, only samples with a $\mathrm{C}_{\mathrm{T}}$ value range $<0.5$ for the replicates were included in the analysis. Exceptions were made for Trpal expression in DRG explants during postnatal days 1 and 2 because of the low expression of TRPA1. Relative fold changes in mRNA levels were calculated by the $\Delta \Delta \mathrm{C}_{\mathrm{T}}$ method using $S d h a$ as a reference standard. The range for the target gene relative to $g p 130^{f l / f l}$ samples as calibrator was calculated by $2^{-\Delta \Delta \mathrm{CT}}$.

ISH: probes. A region complementary to base pairs 957-1761 of murine Trpa1 mRNA (NM_177781.4) was amplified from full-length cDNA by PCR. Specifically designed primer pairs introduced T7 (antisense probe: 5' -TAATACGACTCACTATAGGGGTTCAGGAGGATGTCAGCATTG-3') and SP6 (sense probe; 5'-CATACGATTTAGGTGACACTATAGGAGACCCTGCTTCACAGAG-3') RNA polymerase promoter regions at the $5^{\prime}$ ends of the amplified region. Amplified DNA fragments were visualized by gel electrophoresis and purified by gel extraction using the MinElute Gel Extraction Kit (QIAGEN). Digoxigenin-labeled cRNA was synthesized by in vitro transcription using the DIG RNA Labeling Kit (SP6/T7) according to the manufacturer's instructions (Roche).

Tissue preparation. Lumbar DRGs (L1-L6) were harvested, fixed in 4\% PFA (Fluka/Sigma) for 3-4 h at room temperature, washed three times in $1 \times$ PBS for $10-30 \mathrm{~min}$, and cryoprotected in $25 \%$ sucrose (Merck)/PBS overnight at $4^{\circ} \mathrm{C}$. Tissue samples were embedded in Tissue-Tek OCT Compound (Sakura), snap-frozen in liquid nitrogen, and kept at $-80^{\circ} \mathrm{C}$ until use.

Cryostat sections $(12 \mu \mathrm{m})$ were mounted on Super Frost Plus slides (Thermo Scientific), air-dried for $1-3 \mathrm{~h}$ at room temperature, fixed with $4 \%$ PFA for $30 \mathrm{~min}$, and prehybridized with equilibration buffer containing the following: $12.6 \mathrm{~mm}$ Tris (Roth) at pH 7.5, $185 \mathrm{~mm} \mathrm{NaCl}$ (Sigma), $10 \mathrm{~mm} \mathrm{NaH}_{2} \mathrm{PO}_{4}$ (Merck), 5 mm EDTA (Sigma), 50\% deionized formamide (Sigma), $0.5 \times$ Denhardt's (Sigma) in DEPC-treated $\mathrm{H}_{2} \mathrm{O}$ for 5-15 min at room temperature. Hybridization was performed overnight at $68^{\circ} \mathrm{C}$ in a humidified chamber. cRNA probes were diluted 1:50 in hybridization buffer containing $12.6 \mathrm{~mm}$ Tris (Roth), $\mathrm{pH} 7.5,185 \mathrm{~mm} \mathrm{NaCl}$ (Sigma), $10 \mathrm{~mm} \mathrm{NaH}_{2} \mathrm{PO}_{4}$ (Merck), 5 mm EDTA (Sigma), 50\% deionized formamide (Sigma), 10\% dextrane sulfate (Sigma), $1 \mathrm{mg} / \mathrm{ml}$ yeast RNA (Roche), and $0.5 \times$ Denhardt's (Sigma) in DEPC-treated $\mathrm{H}_{2} \mathrm{O}$. Sections were then washed two times for $30 \mathrm{~min}$ at $68^{\circ} \mathrm{C}$ in $1 \times \mathrm{SSC}$ (Sigma), pH $7.0,25 \%$ formamide, $0.1 \%$ Tween 20 (Sigma), twice for $30 \mathrm{~min}$ and once for $1 \mathrm{~h}$ at room temperature in $100 \mathrm{~mm}$ maleic acid (Sigma), $150 \mathrm{~mm}$ $\mathrm{NaCl}$ (Sigma), and $0.1 \%$ Tween 20 (Sigma), pH 7.5 (MABT). Sections were blocked for $1 \mathrm{~h}$ at room temperature with 20\% FBS (Biochrom) in MABT before overnight incubation with alkaline phosphataseconjugated anti-digoxigenin antibody (Roche; 1:3000) diluted in $20 \%$ FBS/MABT. Sections were washed $3 \times 20 \mathrm{~min}$ in MABT at room temperature and twice 10 min with alkaline phosphatase buffer containing 100 mм Tris, pH 9.5, $50 \mathrm{~mm} \mathrm{MgCl}_{2}$ (Merck), $100 \mathrm{~mm} \mathrm{NaCl}, 0.1 \%$ Tween 20, and $0.024 \%$ levamisol (Fluka/Sigma). Revelation was performed using NBT/BCIP (Roche) in alkaline phosphatase buffer for 22-26 h at room temperature in the dark. The reaction was stopped by 2 washes with $5 \mathrm{~mm}$ EDTA/PBS, before postfixation with $4 \%$ PFA for $30 \mathrm{~min}$ at room temperature and subsequent embedding in Mowiol (Calbiochem).

For FISH, the same protocol was applied for hybridization and subsequent washing and blocking steps. Sections were incubated with alkaline phosphatase-conjugated anti-digoxigenin antibody (Roche; 1:1000), and revelation was performed using 2-hydroxy-3-naphtoic acid-2' phenylanilide phosphate (HNPP)/Fast Red (Roche). Briefly, sections were incubated with a freshly prepared solution of $0.1 \mathrm{mg} / \mathrm{ml} \mathrm{HNPP}$ and $0.25 \mathrm{mg} / \mathrm{ml}$ Fast Red TR for $30 \mathrm{~min}$ at room temperature and then washed in alkaline phosphatase buffer (without levamisol). This procedure was repeated three times. Afterward, sections were washed once in PBS and stained with isolectin B4 (IB4)-Alexa-488 (1:200, Invitrogen) in $\mathrm{PBS}$ for $30 \mathrm{~min}$ at room temperature before embedding in Mowiol. For comparisons between genotypes, sections from equal numbers of animals per genotype ( $g p 130^{f l f l}$ or SNS- $g p 130^{-1-}$ ) were placed on one slide and therefore subject to the same treatment. Sections of four to six DRG were used per animal.

Pictures were taken through an Axiovert 200M (Zeiss) with a Neofluar $40 \times$ oil-immersion objective. NBT/BCIP-stained sections were illuminated using the bright field modus with a constant light intensity and 50 $\mathrm{ms}$ exposure time. Staining intensity was measured as mean gray value per neuron. Per section, gray values of one nonstained neuron were measured as background control. Because gray values correlated inversely with staining intensities, neurons with staining intensities exceeding background by 3.5 times the SD were considered as Trpa1-positive. Sections incubated with sense probe served as negative control and did not reveal any specific staining. HNPP/Fast Red TR staining was visualized using a matching filter set (BP 546/10, Omega; FT 560, BP 575-640, Zeiss) with 300 or $500 \mathrm{~ms}$ exposure time. All pictures were normalized to $500 \mathrm{~ms}$ exposure time and a threshold was applied to discriminate Trpa1positive neurons. Sections hybridized with sense cRNA probes served as negative control and yielded $<4 \%$ of positive neurons with the applied threshold. Approximately 300-1000 neurons per animals were analyzed, and data are displayed as means per animal. Quantification was performed using ImageJ (National Institutes of Health) (Schneider et al., 2012). All analyses were performed by an examiner who was blinded to genotype and sense/antisense staining.

Microfluorimetric calcium measurements. Twenty-four hour DRG neuron cultures were incubated with $6 \mu \mathrm{M}$ calcium $\left(\mathrm{Ca}^{2+}\right)$-sensitive dye fura-2 AM (Invitrogen) in TNB medium (Biochrom) for $30 \mathrm{~min}$ at $37^{\circ} \mathrm{C}$ in $5 \% \mathrm{CO}_{2}$ in a humidified incubator. Then cells were washed and kept in 
extracellular solution containing the following (in mM): $145 \mathrm{NaCl}, 5 \mathrm{KCl}, 2 \mathrm{CaCl}_{2}, 1 \mathrm{MgCl}_{2}, 10$ D-glucose (all from Merck) and 10 HEPES (Roth), at $\mathrm{pH} 7.3$ adjusted with $\mathrm{NaOH}$ (Merck). Ratiomeric measurements were performed using a Zeiss Axiovert 200 microscope (Zeiss) with a Fluor $20 \times / 0.75$ NA objective (Zeiss). Fura-2 was excited consecutively at 340 and $380 \mathrm{~nm}$ (excitation time: $55 \mathrm{~ms}$ ) with a polychrome IV monochromator (TILL Photonics), and fluorescence intensities were filtered by a $510 \mathrm{~nm}$ long pass filter and recorded with a CCD camera (Roper Scientific) at $1 \mathrm{~s}$ intervals. For data acquisition, MetaFluor 7.1.2.0 (Molecular Devices) was used, and off-line analysis was performed with Excel 2007 (Microsoft). Data traces were filtered by a simple 3 -point moving average. All chemicals were diluted in extracellular solution and applied by a gravity-driven perfusion system (Dittert et al., 1998). Only cells with a low and stable baseline $\mathrm{Ca}^{2+}$ signal within the first 120 s of the protocol were used for analysis. The inclusion criterion for cells responsive to CA or capsaicin was set to $125 \%$ of the baseline $\mathrm{Ca}^{2+}$ signal $10 \mathrm{~s}$ before stimulation. The threshold for a positive response to 5-nitro-2-(3-phenylpropylamino) benzoic acid (NPPB) was defined by the highest $\mathrm{Ca}^{2+}$ signal in TRPA1 ${ }^{-1-}$ DRG neurons during stimulation. Viability of the neurons was tested with a $10 \mathrm{~s}$ pulse of $25 \mathrm{~mm}$ potassium chloride solution in each experiment. All chemicals were purchased from Sigma.

Statistical analysis. Statistical analysis was performed per animal $(N)$, and per nerve fiber or number of cells $(n)$ for the single-nerve fiber recording and calcium imaging data. For statistical analysis, Sigma Stat 3 and Origin Pro 8 software were used, and the data are presented as mean \pm SEM unless otherwise indicated. Depending on sample size, distribution, and number of variables, one-way ANOVA with post Tukey test, unpaired Student's $t$ test, two-way ANOVA, or the nonparametric Mann-Whitney $U$ test for comparison between groups, and $\chi^{2}$ test with Yates correction as well as Kolmogorov-Smirnov test were used as stated in the respective text. Differences were considered statistically significant at $p<0.05$.

\section{Results}

Reduced mechanonociception in SNS-gp130 ${ }^{-/-}$mice

Because IL- 6 sensitizes nociceptors to mechanical stimuli and its receptor gp130 is required for the maintenance of mechanical hypersensitivity in several rodent models of pathological pain (Brenn et al., 2007; Quarta et al., 2011), we hypothesized that gp130 may be an important switch for the function of mechanonociceptors. Therefore, we assessed the reflex withdrawal thresholds to mechanical stimuli of increasing strength of $g p 130^{f l / f l}$ and $S N S-g p 130^{-/-}$mice with a calibrated set of von Frey filaments. Response frequencies of SNS- $g p 130^{-/-}$mice were significantly lower than those of $g p 130^{f l / f l}$ mice (two-way ANOVA: genotype: $F_{(1,125)}=38.99051 ; p<0.00001$, force: $F_{(6,125)}=$ 40.08017; $p<0.00001$, genotype $\times$ force: $F_{(6,125)}=1.91561, p=$ $0.08432 ; N=9$; Fig. $1 A$ ), and the median mechanical withdrawal threshold was significantly higher for SNS- $g p 130^{-/-}$than for $g p 130^{f l f l}$ mice $\left(g p 130^{f l f l}: 16 \mathrm{mN}\right.$ with $8 \mathrm{mN}$ and $19.3 \mathrm{mN}$ as lower and upper quartile vs $S N S-g p 130^{-/-}: 27.3 \mathrm{mN}$ with $24 \mathrm{mN}$ and $30.65 \mathrm{mN}$ as lower and upper quartile; Mann-Whitney $U$ test, $\mathrm{T}=54, p=0.00619 ; N=9$; Fig. $1 B$ ). Both parameters indicated
B

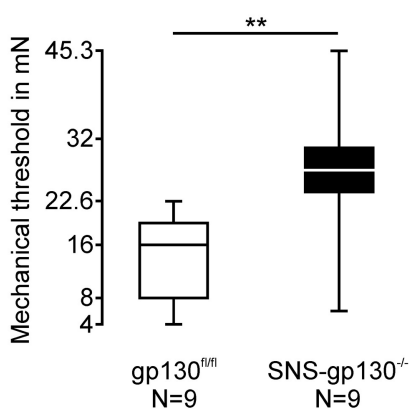

D

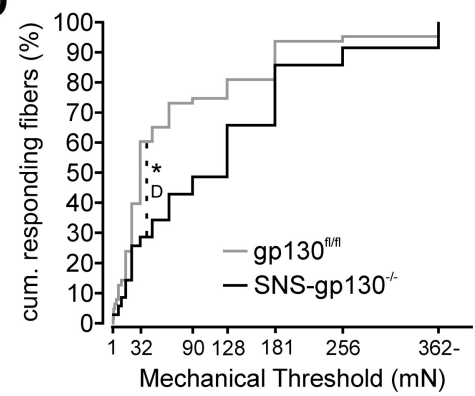

Mechanical Threshold $(\mathrm{mN})$

Figure 1. SNS-gp $130^{-/-}$mice were less sensitive to mechanical stimulation. $A$, SNS-gp $130^{-/-}$mice responded with signif-

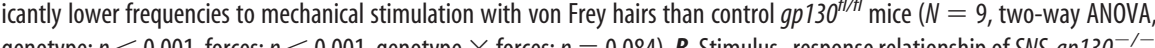
mice in the von Frey test was shifted toward stronger forces as SNS-gp $130^{-1-}$ mice exhibited significantly higher mechanical percentiles. C, In vitro, the distribution of mechanical thresholds was significantly shifted toward stronger stimuli for unmyelinated Mann-Whitney Utest $p<0.05)$. The cumulative distribution showed that a significantly lower percentage of fibers responded to medium to high mechanical forces in SNS-gp $130^{-1-}$ mice. ${ }^{*} p<0.05 .{ }^{* *} p<0.01$.

that SNS-gp $130^{-/-}$mice were less sensitive to mechanical stimulation than control mice. Because the deletion of gp130 was restricted to $\mathrm{Na}_{\mathrm{v}} 1.8$-expressing unmyelinated sensory neurons, we analyzed the mechanical thresholds of C-fibers in SNS$g p 130^{-/-}$mice using single-nerve fiber recordings in a skinsaphenous nerve in vitro preparation. Mechanical probing of the receptive field with von Frey filaments revealed that the mechanical activation thresholds of C-mechano- and polymodal nociceptors were shifted to stronger forces in SNS-gp130 ${ }^{-1-}$ mice (activation threshold: $g p 130^{f l / f l}$ : median: $32 \mathrm{mN}$ with $22.6 \mathrm{mN}$ and $109 \mathrm{mN}$ as lower and upper quartile vs $S N S-g p 130^{-1-}$ : median: $128 \mathrm{mN}$ with $27.3 \mathrm{mN}$ and $181 \mathrm{mN}$ lower and upper quartile, Mann-Whitney $U$ test, $\mathrm{T}=2065.5, p=0.01369$; Fig. $1 C$ ), suggesting that nociceptors were less sensitive to mechanical stimulation in SNS- $g p 130^{-/-}$mice compared with $g p 130^{f l / f l}$ mice. In accordance with the behavioral experiments, the greatest differences were observed in the medium to high force range with the maximal accumulated difference at $32 \mathrm{mN}\left(g p 130^{f l / f l}\right.$ vs SNS-gp130-/- Kolmogorov-Smirnov Test, D: 0.32381, $p=$ 0.01219; Fig. 1D).

\section{Reduced expression of Trpa1 mRNA in SNS-gp130-/- DRG neurons}

gp130 signaling regulates mRNA expression in target cells classically via the JAK-STAT or via alternative pathways (Heinrich et al., 2003). A commercial genome-wide mRNA expression screen was used to compare expression levels of ion channels between $g p 130^{f l f l}$ and SNS-gp130-/- DRG explants. Out of the 177 ana- 
A

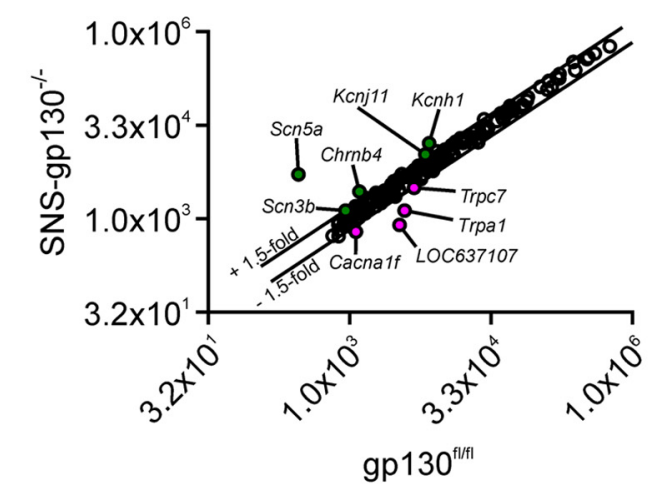

C

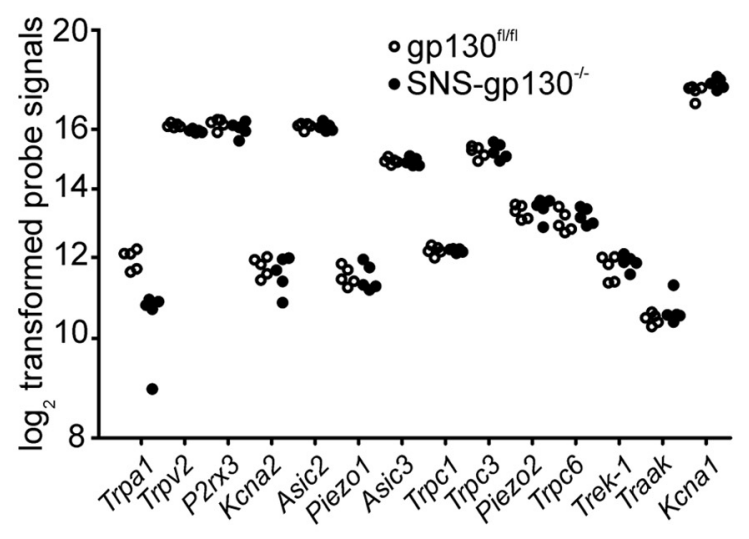

B

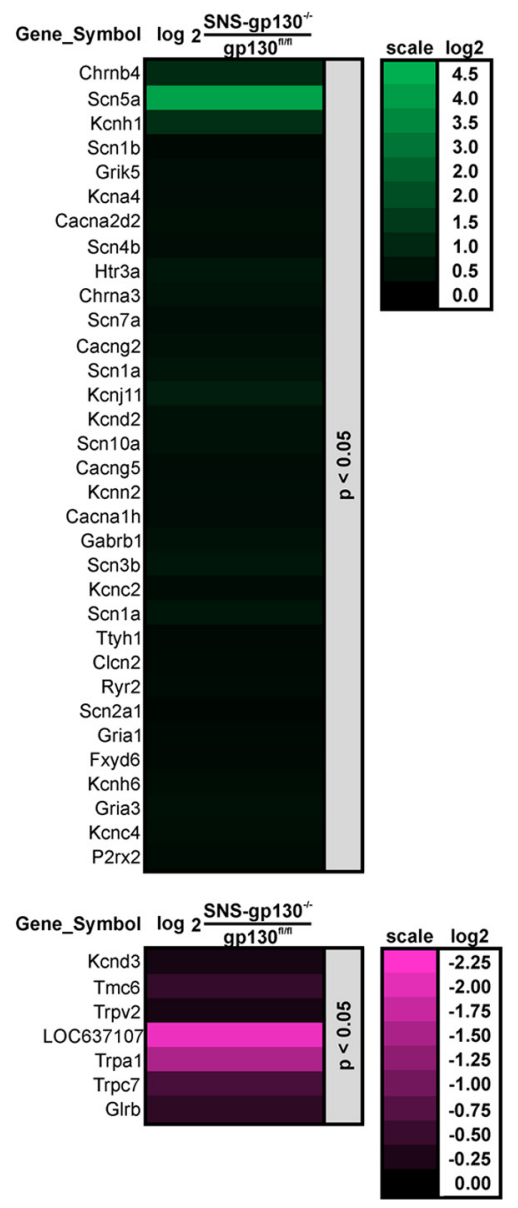

Figure 2. Genome-wide mRNA expression profiling assay. A, Average ion channel expression intensities in SNS-gp $130^{-/-}$compared with $g p 130^{f / f l}$ DRG explants (N $\left.=5\right)$. Depicted are the means of the quantile-normalized signals. The linear values are shown in a $\log _{2}$ scaling. FDR-adjusted $p$ values for deregulated genes: $S c n 5 a, p=0.162797384 ; K c n h 1, p=0.309818818 ; C h r n b 4$, $p=0.112616368 ; K c n j 11, p=0.36698117 ;$ Scn3b, $p=0.396426446 ;$ Trpc7, $p=0.378056322 ;$ Cacna1f, $p=0.5246788 ;$ Trpa1, $p=0.363034703 ;$ LOC637107, $p=0.31986923 . B$, Heat map showing ion channel gene expression in SNS-gp $130^{-/-}$versus gp $130^{f / f / f}$ DRG explants. Genes, which are upregulated (green, left) or downregulated (magenta, right), are sorted by their unadjusted $p$ value. Only genes with $p<0.05$ are shown. $C$, Expressed ion channels with a putative function in mechanotransduction. Expression levels are shown as $\log _{2}$ quantile-normalized signal values for

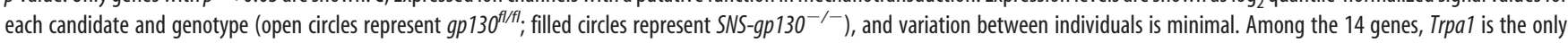
deregulated ion channel. For fold change in expression levels, see Table 1.

lyzed genes, 5 candidates were at least 1.5 -fold upregulated, and 4 candidates demonstrated a 1.5 -fold (or higher) downregulation in SNS-gp $130^{-1-}$ mice (Fig. $2 A, B$ ). Within the group of ion channels with a putative mechanosensitive function, the screen detected 14 of 17 possible targets, but only Trpa 1 mRNA expression levels were $>1.5$-fold lower in DRG explants of SNS$g p 130^{-/-}$mice compared with $g p 130^{f / f l}$ mice (Fig. 2C; Table 1). Because the deregulation of Trpal mRNA between $g p 130^{f l f l}$ and $S N S-g p 130^{-1-}$ mice revealed a relatively high FDR-adjusted $p$ value, we confirmed this result by quantifying Trpal mRNA levels in thoracic and lumbar DRG explants of $g p 130^{f l f l}$ and SNS-gp $130^{-/-}$mice with TaqMan qRT-PCR. Explants of SNS$g p 130^{-1-}$ mice expressed significantly less Trpal mRNA than $g p 130^{f l / f l}$ mice $\left(g p 130^{f l / f l}: 1.03 \pm 0.13\right.$ vs SNS-gp130 $10^{-/-}: 0.38 \pm$ $0.05, N=5-7$; Mann-Whitney $U$ test, $\mathrm{T}=50, p=0.00253$; Fig. 3A). Furthermore, we assessed the Trpa1 mRNA expression levels in primary neuron cultures of SNS-gp $130^{-/-}$and $g p 130^{f / f l}$ DRG. Trpa1 expression levels were three times lower in neuron cultures of SNS-gp $130^{-1-}$ compared with $g p 130^{f / f l}$ mice $\left(g p 130^{f / f l}\right.$ : $1.00 \pm 0.04$ vs SNS-gp130-/- $: 0.32 \pm 0.06, N=3-5$; MannWhitney $U$ test, $\mathrm{T}=21, p=0.0357$; Fig. $3 B$ ). In contrast, expres-
Table 1. Genome-wide mRNA expression screen of mechanotransducer ion channel candidates

\begin{tabular}{lll}
\hline Gene symbol & $\begin{array}{l}\text { Linearized fold change: SNS-gp130 } \\
\text { versus gp130 }\end{array}$ & Net fold change $>1.5$ \\
\hline Trpa1 & -2.8538 & + \\
Trpv2 & -1.1479 & - \\
P2rx3 & -1.1412 & - \\
Kcna2 & -1.1381 & - \\
Asic2 & -1.0220 & - \\
Piezo1 & -1.0216 & - \\
Asic3 & -1.0137 & - \\
Trpc1 & 1.0033 & - \\
Trpc3 & 1.0173 & - \\
Piezo2 & 1.0765 & - \\
Trpc6 & 1.1097 & - \\
Trek-1 & 1.1177 & - \\
Traak & 1.1525 & - \\
Kcna1 & 1.2410 & - \\
Asic1 & Not detectable & - \\
Kcnq4 & Not detectable & - \\
Trpv4 & Not detectable & - \\
\hline
\end{tabular}


sion levels of Trpv1 and Trpv4, two members of the TRP superfamily of ion channels expressed in nociceptive neurons, were unaltered in DRG explants of SNS-gp $130^{-1-}$ mice (Fig. 3B). This suggests that gp130 deletion specifically targets Trpal expression, whereas expression of other ion channels of the TRP family, which substantially contribute to hypernociception in mouse models of pathological pain, is not regulated by gp130 (for review, see Dubin and Patapoutian, 2010). Moreover, OSM knock-out mice reveal a reduced response in the formalin test, which largely depends on TRPA1 (Morikawa et al., 2004; McNamara et al., 2007). Last, to rule out an unspecific effect of the Cre-recombinase on Trpal mRNA expression, we assessed Trpal mRNA expression levels in lumbar DRG explants of SNS-Cre mice. Trpal expression was similar for $g p 130^{f l f l}$ and SNS-Cre mice, in contrast to SNS-gp130 $130^{-/}$mice, which expressed significantly less Trpa1 mRNA than both control strains $\left(g p 130^{f l f l}: 1.02 \pm 0.08\right.$ vs SNS-Cre: $0.87 \pm 0.07$ vs SNS-gp130 $130^{-1-}$ : $0.51 \pm 0.03, N=7$ or 8 ; one-way ANOVA $F_{(2,22)}=15.96582, p=0.00007$; Tukey post test $g p 130^{f l / f l}$ vs $S N S$-Cre $p=0.21981$, $g p 130^{f l f l}$ vs $S N S-g p 130^{-/-} p=0.00019$, SNS-Cre vs SNS-gp130 ${ }^{-1-} p=0.00269$; Fig. 3B).

Functional recombination and deletion of gp130 in $\mathrm{Na}_{\mathrm{v}} 1.8$-Cre mice start at the day of birth (P0), nearly coinciding with the occurrence of Trpal expression (Agarwal et al., 2004; Hjerling-Leffler et al., 2007). We therefore assessed whether the deficit in Trpal expression was already present during this early postnatal period. In DRG of SNS-gp130 $0^{-/-}$and control mice, Trpal mRNA expression started to be detectable within the first postnatal week. In control mice, Trpal mRNA expression increased to $42.9 \%$ of the adult expression, at up to postnatal day P14. However, in SNS$g p 130^{-1-}$ DRG, Trpal mRNA was low from P0 and remained significantly reduced at postnatal days P7 and P14 $\left(g p 130^{f l f l}\right.$ vs SNS-gp130 ${ }^{-/-}: \mathrm{P} 1+2: 0.023 \pm 0.002$ vs $0.011 \pm 0.000, \mathrm{~T}=6$, $p=0.01273$; P7: $0.191 \pm 0.011$ vs $0.095 \pm 0.007, \mathrm{~T}=21, p=$ 0.00179; P14: $0.429 \pm 0.024$ vs $0.167 \pm 0.009, \mathrm{~T}=84, p=$ 0.00031 , all Mann-Whitney $U$ test; Fig. $3 C$ ). These results indeed suggest that gp130 acts as a switch for Trpal expression and the postnatal development of the nociceptive system.

\section{Deregulation of $\operatorname{Trpa} 1 \mathrm{mRNA}$ expression in nonpeptidergic neurons of $S N S-g p 130^{-/-}$mice}

DRG contain all populations of sensory neurons, which can be defined by their function (e.g., as mechanonociceptors of the C-fiber class) and by certain immunohistochemical markers that are associated with certain neuron types. Even nociceptive primary afferents represent heterogeneous neuronal subpopulations. These can be primarily divided into peptidergic neurons,
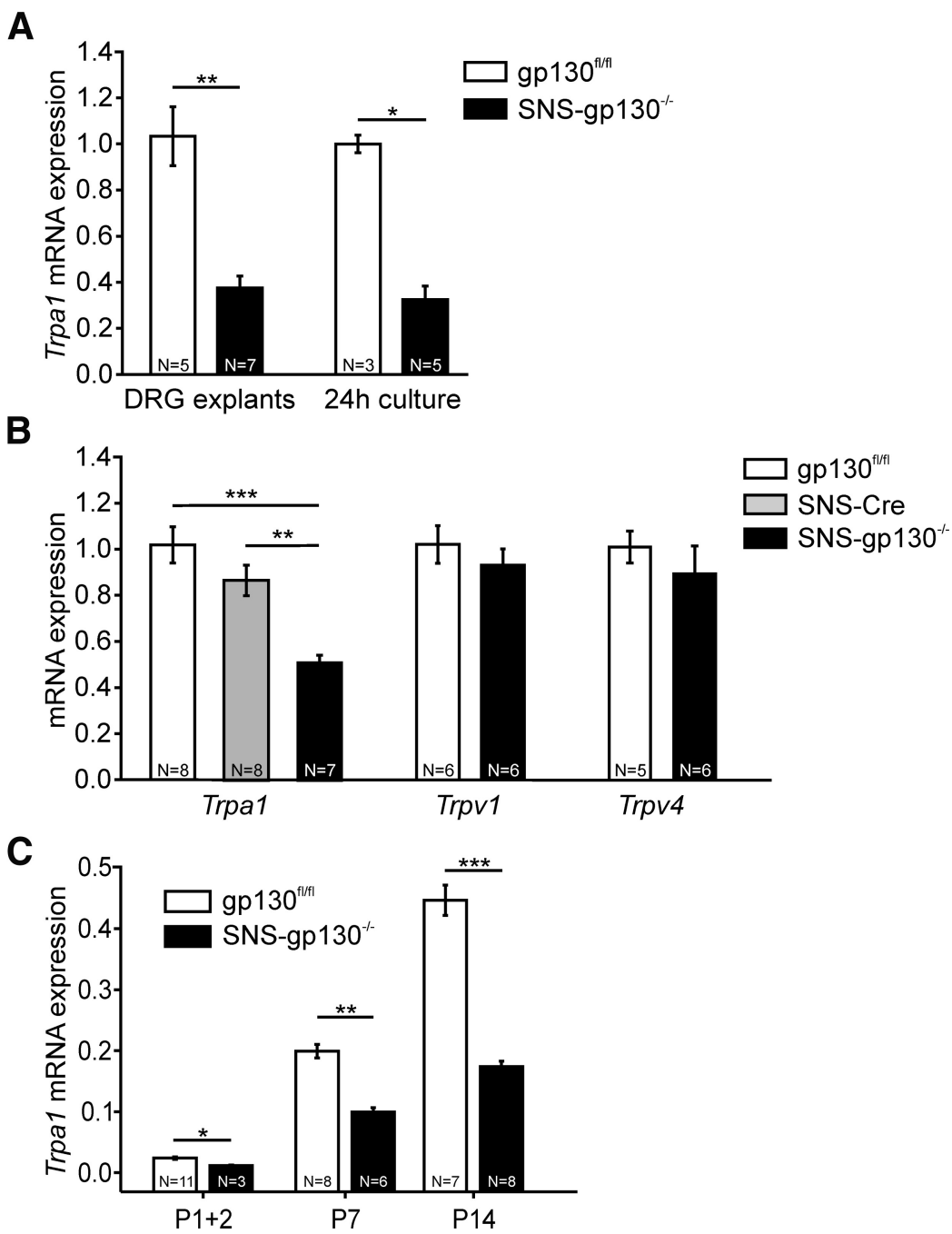

Figure 3. Neuronal gp130 was essential for Trpa1 mRNA expression in DRG. $\boldsymbol{A}$, TaqMan mRNA analysis revealed significantly

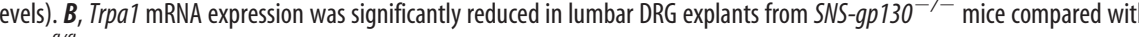
$f / f f l$ and SNS-Cre, which were not significantly different. Furthermore, Trpv1 and Trpv4 mRNA levels were similar between and SNS-gp130-/- mice. C, Trpa1 mRNA expression of lumbar DRG explants within the first 14 postnatal days. In SNS-gp $130^{-/-}$mice, Trpa1 mRNA expression was already reduced at P1-P14. Expression levels are normalized to adult $g p 130^{f / f f}$ mice. ${ }^{*} p<0.05$. ${ }^{* *} p<0.01$. ${ }^{* *} p<0.001$.

expressing the neuropeptides substance $\mathrm{P}$ or calcitonin generelated peptide, and nonpeptidergic neurons, which bind IB4. At the same time, the differential expression of specific receptor molecules determines the function of the nociceptor subpopulations (for review, see Dubin and Patapoutian, 2010). Therefore, it was important to identify the DRG subpopulation that requires gp130 for Trpal expression. We used nonradioactive ISH to assess and localize Trpal mRNA expression in subpopulations of lumbar DRG (L1-L6) of SNS-gp130-/- and control mice. First, chromogenic ISH with NBT/BCIP was used to determine riboprobe specificity and general Trpal mRNA expression. In contrast to the sense probe, the Trpal antisense probe produced a specific staining in the DRG neurons (Fig. $4 A$ ). In $g p 130^{f l f l}$ sections, $23.1 \pm 4.4 \%$ of the neurons stained positively for Trpal mRNA, whereas SNS-gp130-1- mice showed a significantly lower percentage of Trpa1-positive neurons (7.5 $\pm 1.4 \%$; $N=3$, 4-6 DRG per animal, sections/DRG; unpaired $t$ test, $t=$ 3.3577706, $p=0.02836$; Fig. $4 B, C)$. These results support the 


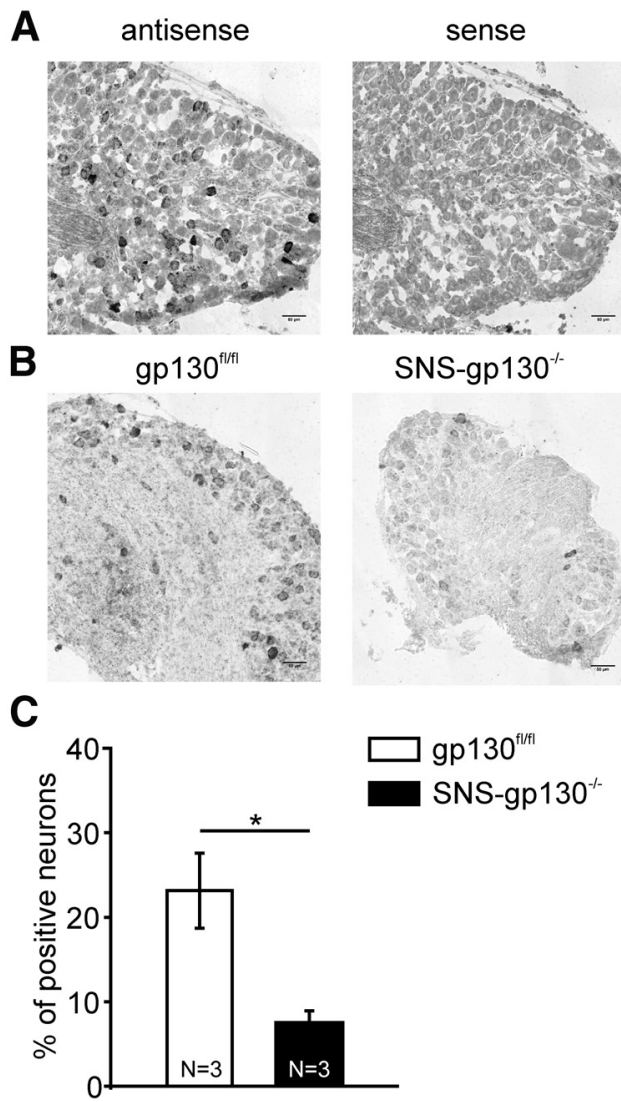

Figure 4. Reduced Trpa $1 \mathrm{mRNA}$ levels in DRG sections of SNS-gp130-/- mice. A, ISH with Trpa1 antisense riboprobe produced a selective staining of Trpa1-expressing neurons, whereas sense probes did not show specific staining in the lumbar DRG sections. Scale bar, $50 \mu \mathrm{m} . \boldsymbol{B}$, Samples of $g p 130^{f / f f}$ and SNS-gp $130^{-/-}$lumbar DRG sections with Trpa1 antisense riboprobe display reduced Trpa $1 \mathrm{mRNA}$ labeling in SNS-gp $130^{-1-}$ sections. Scale bar, $50 \mu \mathrm{m}$. C, Quantification of the ISH labeling in lumbar gp $130^{f / / f}$ and SNS-gp $130^{-/-}$sections. SNS-gp $130^{-/-}$ sections reveal significantly lower numbers of Trpa 1 expressing neurons. ${ }^{*} p<0.05$.

TaqMan qPCR data showing lower Trpa1 mRNA expression levels in SNS-gp130 ${ }^{-/-}$DRG explants compared with $g p 130^{f l f l}$ mice.

As mentioned above, nociceptive neurons can generally be classified into peptidergic and nonpeptidergic neurons. Although previous studies report contrasting results about Trpa1 mRNA expression in nonpeptidergic neurons, a recent study by Barabas et al. (2012) suggests that TRPA1 function is primarily associated with IB4-positive DRG neurons (Story et al., 2003; Bautista et al., 2005; Obata et al., 2005; Caspani et al., 2009; Kim et al., 2010). To assess the differential Trpal expression in nonpeptidergic versus all DRG neurons, DRG sections were colabeled with AlexaFluor488-conjugated IB4. Because the dark blue NBT/BCIP precipitate can quench fluorescent dyes, HNPP/ FastRed TR was used as an alternative substrate for the alkaline phosphatase for these experiments. The percentage of IB4-positive neurons was unchanged between $g p 130^{f l f l}$ and SNS- $g p 130^{-/-}$mice $\left(g p 130^{f l f l}: 34.2 \pm 3.3 \%\right.$ vs $S N S-g p 130^{-/-}: 33.6 \pm 2.1 \%, 4-6$ sections per animal, $N=5$; Fig. $5 A-C$ ), which is in accordance with our previous study (Andratsch et al., 2009). In $g p 130^{f l f l}$ lumbar DRG sections, $18.9 \pm$ $3.6 \%$ of the neurons were Trpa1-positive, whereas SNS-gp130 mice revealed a significantly lower percentage of Trpa1-positive neurons $(8.3 \pm 1.7 \%$; $4-6$ sections per animal, $N=5$; MannWhitney $U$ test, $\mathrm{T}=39, p=0.01587$; Fig. $5 D-F)$. A total of $40 \%$ of the IB4-positive neurons expressed Trpa1 mRNA in DRG sections from $g p 130^{f l / f l}$ mice. In SNS- $g p 130^{-/-}$mice, this percentage was threefold lower $\left(g p 130^{f l f l}: 40.0 \pm 6.0 \%\right.$ vs SNS-gp130-/$13.1 \pm 3.2 \%$; Mann-Whitney $U$ test, $\mathrm{T}=40, p=0.00794$; Fig. $5 G-I)$. On the other hand, only $5 \%-9 \%$ of IB4-negative DRG neurons expressed Trpa1, and no significant difference in this neuron population was detected between the two genotypes $\left(g p 130^{f l f f l}: 9.0 \pm 3.2 \%\right.$ vs SNS-gp130 ${ }^{-/-}: 4.8 \pm 1.4 \%$; MannWhitney $U$ test, $\mathrm{T}=34, p=0.22222$ ). Together, these findings support the hypothesis that the presence of gp130 is essential for Trpa1 expression in IB4-positive nociceptive neurons.

\section{Regulation of Trpa1 mRNA expression via JAK-STAT signaling}

gp130-dependent cytokines signal via activation of the JAKSTAT and MAP kinase pathway (Heinrich et al., 2003; Pellegrino and Habecker, 2013). In primary cultures of DRG neurons, both the JAK inhibitor I and the STAT inhibitor (Stattic) significantly decreased Trpal mRNA expression levels (JAK inhibitor I group: control: $1.03902 \pm 0.1421$ vs inhibitor: $0.33592 \pm 0.03694, \mathrm{~T}=$ $57, p=0.00216$; Stattic group: control: $1.01725 \pm 0.08066$ vs inhibitor: $0.63475 \pm 0.08534, \mathrm{~T}=54, p=0.01515 ; N=6$; all Mann-Whitney $U$ test; Fig. 6). Expression levels of the housekeeping genes Sdha, Gapdh, and $18 S$ were similar in Stattictreated and control samples $(N=2$; data not shown). Our data indicate that Trpa1 mRNA expression is regulated by JAK-STAT signaling pathways. Together with the reduced Trpa1 mRNA expression in SNS-gp130 ${ }^{-/-}$DRG neurons, this suggests that intact gp130-JAK-STAT signal transduction is critically important for Trpa1 mRNA transcription.

\section{Reduced responsiveness to TRPA1 agonists in SNS-gp130 cultured sensory neurons}

TRPA1 is a calcium-permeable ion channel that is activated by numerous pungent substances. Mustard oil and CA are the most commonly used activators of TRPA1 (Bandell et al., 2004; Jordt et al., 2004; Macpherson et al., 2007). In $g p 130^{f l f l}$ cultures, $41.9 \%$ ( 52 of $124, N=3$ ) of the neurons responded to a $90 \mathrm{~s}$ pulse of 200 $\mu \mathrm{M}$ CA with a calcium transient, whereas a significantly smaller proportion of neurons was activated by CA in SNS-gp130 cultures $\left(11.6 \%, 14\right.$ of $120, N=3 ; \chi^{2}=26.80203$ with 1 degree of freedom: $p=0.0000002$; Fig. $7 A, B)$. At the same time, responsiveness to $0.3 \mu \mathrm{M}$ of the TRPV1 agonist capsaicin was similar in $g p 130^{f l f l}$ and SNS- $g p 130^{-/-}$cultures $\left(g p 130^{f l f l}: 43\right.$ of 124 neurons $=34.6 \%$ vs SNS-gp130 ${ }^{-/-}: 39$ of 110 neurons $=35.5 \%, N=$ 3 ; Fig. $7 A, B)$. This provides functional and translational evidence supporting the differences in Trpa1 mRNA expression profiles reported above.

Apart from CA, the chloride channel blocker NPPB has been reported to selectively activate heterologously expressed TRPA1. However, reports on sensory neurons are as yet not available for this compound (Liu et al., 2010). NPPB caused a transient increase in intracellular $\mathrm{Ca}^{2+}$ concentration in cultured DRG neurons obtained from control $\left(T R P A 1^{+/+}\right)$mice, but responses to NPPB were virtually absent in neurons obtained from TRPA $1^{-/-}$ mice (median ratio increase: TRPA1 $1^{-/-}: 0.12169$ with 0.08273 and 0.16727 as lower and upper quartile, $n=101, N=3$; TRPA $1^{+/+}: 0.23691$ with 0.09383 and 0.7028 as lower and upper quartile, $n=53, N=2$; Fig. $7 C$ ). This suggests that the calcium transient observed was in response to NPPB exposure and was indeed due to its agonistic action on TRPA1. Using NPPB as a second TRPA1 agonist, we obtained a reduction of TRPA1 responsiveness in SNS-gp130-/- DRG cultures, with a similar degree to the one observed with CA. In $g p 130^{f l f l}$ cultures, $26.3 \%$ (31 of $118, N=3$ ) of the neurons responded to NPPB with a mean 
suprathreshold ratio increase of $1.52 \pm$ 0.12 (Fig. 7D). However, only 10.8\% (18 of $167, N=4)$ of the SNS-gp130 $0^{-/-}$neurons responded with a mean TRPA1mediated ratio increase of $1.11 \pm 0.11$ to the $60 \mathrm{~s} 100 \mu \mathrm{M}$ NPPB pulse. The proportion and the magnitude of the TRPA1mediated ratio increase were significantly lower than in control cultures (proportion: $\chi^{2}=10.59433$ with 1 degree of freedom: $p=0.00113$; ratio increase: unpaired $t$ test: $t=2.33996$ with 47 degrees of freedom: $p=0.02358$; Fig. 7D). Therefore, we conclude from these data, with two different agonists, that the functional expression of TRPA1 is reduced in primary DRG cultures of SNS-gp130-/mice.

\section{Attenuated nocifensive response to the TRPA1 agonist CA in SNS-gp130 ${ }^{-/-}$ mice in vivo}

Finally, we assessed whether the downregulation of TRPA1 expression in transgenic gp130 mice was functionally relevant in vivo. Injection of CA into the hindpaw of control mice induced spontaneous nocifensive behavior as reflected by a mean licking duration of $25.9 \pm 8.4 \mathrm{~s}$ and mean number of licking events of $7.3 \pm$ 1.6.

Control vehicle injection did not evoke nocifensive reactions during the 5 min observation period (mean licking duration $<1$ $s$; mean number of licking events $<1$; data not shown). SNS$g p 130^{-/-}$mice revealed a significantly attenuated response to the TRPA1 agonist (licking duration: $7.0 \pm 4.0 \mathrm{~s}, \mathrm{~T}=75, p=$ 0.02890 ; licking events: $1.8 \pm 0.9, \mathrm{~T}=79, p=0.00591$; MannWhitney $U$ test; $N=7$ or 8 ; Fig. 8 ). These data indicate that downregulation of TRPA1 in mice with a null mutation of gp130 in $\mathrm{Na}_{\mathrm{v}} 1.8$-expressing nociceptors is relevant for responsiveness to noxious stimuli requiring TRPA1 in vivo. Overall, our data suggest that gp130 in nociceptive neurons is an essential switch for TRPA1 expression and absence of gp130 from nociceptive primary afferents causes severe deficits in acute mechanonociception and nocifensive reactions to TRPA1 agonists.

\section{Discussion}

In the present study, we addressed the importance of neuronally expressed gp130 for mechanonociception, using a conditional transgenic gp130 knock-out mouse model previously generated in our group (Andratsch et al., 2009; Quarta et al., 2011). In behavioral tests and electrophysiological recordings, SNS-gp130-/- mice revealed reduced mechanonociception compared with control mice (Fig. 1). This deficit in mechanonociception was accompanied by low Trpal mRNA expression levels, predominantly in nonpeptidergic neurons of SNS-gp130-/- mice from early postnatal development onwards (Figs. 234-5). Downstream of gp130, JAK and STAT were involved in the regulation of Trpal transcription (Fig. 6), and the reduction in Trpal expression in SNS-gp130-/mice was associated with functional deficits in vitro and in vivo (Figs. 7 and 8 ).

Cytokines of the IL- 6 family use a combination of ligand binding $\alpha$-receptors (IL-6R $\alpha$, IL-11R $\alpha$, and $\operatorname{CNTFR~} \alpha$ ) and the signal transducing receptor subunits gp130, LIFR, and OSMR. Com-
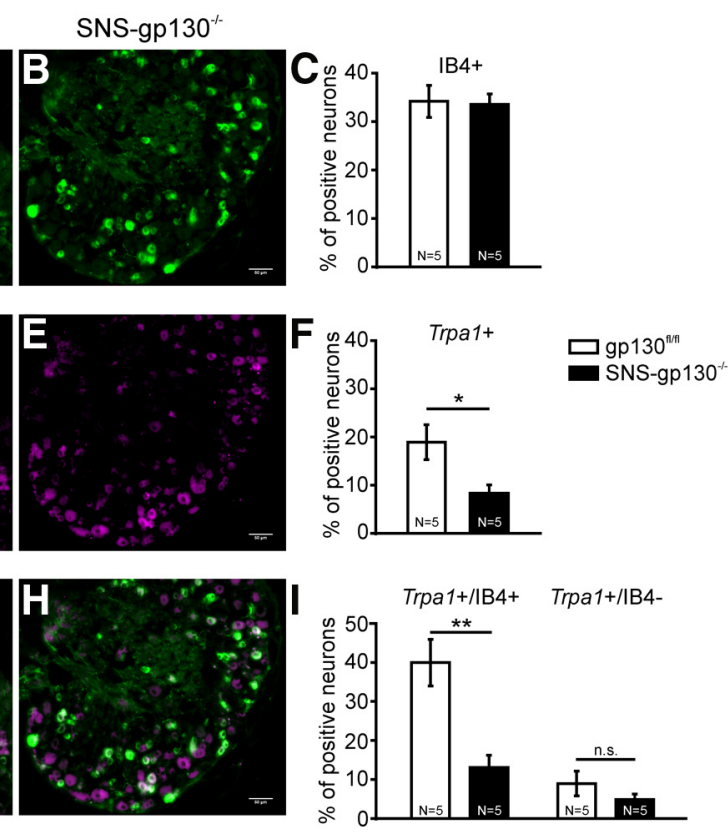

Figure 5. Trpa1 deficiency was predominantly observed in IB4-binding nociceptive neurons. $A, B$, Staining for IB4 + neurons in control mice, Trpa1 mRNA was predominantly expressed in IB4-positive neurons. In SNS-gp130-/- mice, reduction of Trpa1 was most noticeable in the IB4-positive population. n.S., Not significant $(p>0.05) .{ }^{*} p<0.05 .{ }^{* *} p<0.01$.

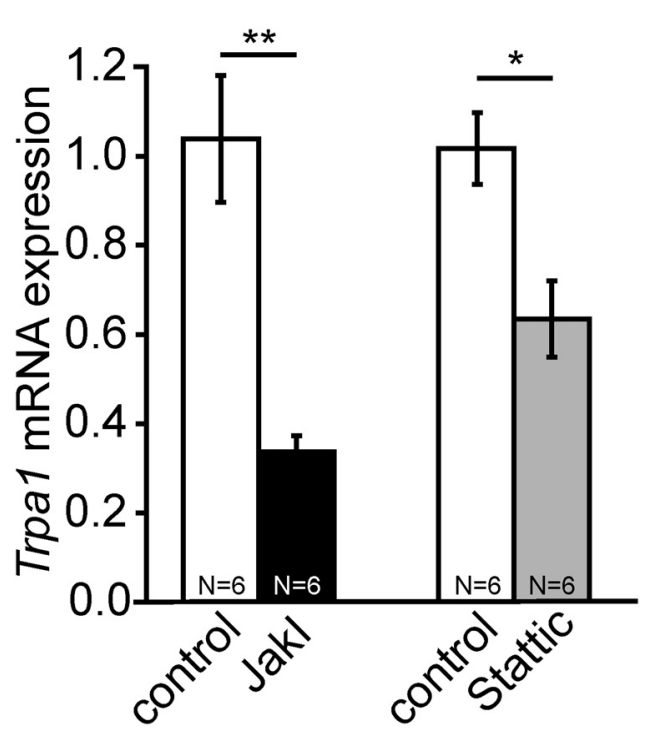

Figure 6. Expression of Trpa1 mRNA was controlled by the JAK-STAT pathway. TaqMan mRNA analysis revealed significantly reduced Trpa1 expression levels in DRG neurons incubated with a selective JAK inhibitor I (JAKI, $1 \mu \mathrm{m}$ ) or a STAT inhibitor, with selectivity for STAT3 (Stattic, $1.5 \mu \mathrm{m}) .{ }^{*} p<0.05 .{ }^{* *} p<0.01$.

mon to all these receptor combinations is the essential requirement of at least one gp130 subunit for signal transduction. After activation, gp130 acts via classical JAK-STAT signaling and activation of the mitogen-activated protein kinase (MAPK) pathway (for review, see Heinrich et al., 2003). In addition to transcriptional regulation, IL- 6 has been shown to enhance capdependent translation by mediating eIF4F cap complex formation, a process that allows control of translation in DRG neurons and is relevant for mechanical allodynia (Melemedjian et al., 
A
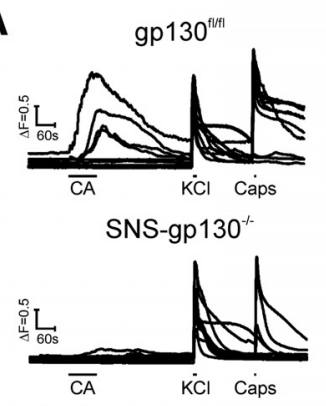

C
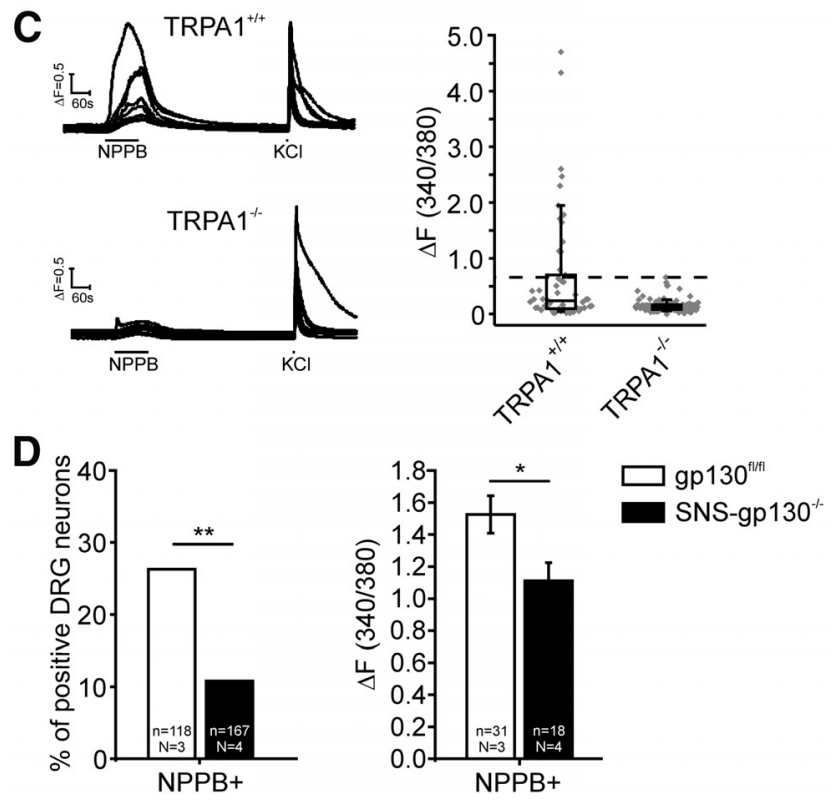

Figure 7. Functional TRPA1 expression was reduced in cultured primary DRG neurons of SNS-gp $130^{-1-}$ mice. $A$, Calcium imaging sample traces of primary neurons stimulated with the TRPA1-agonist CA (200 $\mu \mathrm{m})$, high potassium chloride ( $\mathrm{KCl}, 25 \mathrm{~mm}$ ) and TRPV1-agonist capsaicin $(0.3 \mu \mathrm{M}) . \boldsymbol{B}$, The percentage of neurons responding to CA was significantly decreased in SNSgp $130^{-1-}$ cultures. In contrast, the responsiveness to capsaicin (Caps) was unchanged. $\boldsymbol{C}$, Calcium imaging sample traces of primary neurons stimulated with NPPB (100 $\mu \mathrm{M})$ and $\mathrm{KCl}(25$ $\mathrm{mm})$. Responses to NPPB were greatly diminished in $\mathrm{TRPA1}^{-1-}$ neurons. Magnitude of ratio increase in response to stimulation with $100 \mu \mathrm{M} N P P B$ in $\operatorname{TRPA1}^{+/+}(n=53, N=2)$ and TRPA1 $^{-1-}(n=101, N=3)$ neuronal cultures. The highest ratio increase in TRPA1 ${ }^{-1-}$ cultures was considered as threshold for TRPA1-mediated responses to NPPB. TRPA ${ }^{+/+}$and $T_{R P A 1^{-1-}}$ : boxes represent median as well as lower and upper quartile; whiskers represent the 10 th and 90 th percentiles. $D$, Percentage and ratio increase of neurons responding to NPPB with a suprathreshold ratio increase in $g p 130^{f / f l}$ and SNS-gp $130^{-/-}$neuron cultures. In SNSgp $130^{-/-}$cultures, the number of neurons responding to NPPB was significantly decreased, and NPPB-responsive cells showed a significantly lower ratio increase to the stimulus. ${ }^{*} p<$ $0.05 .{ }^{* *} p<0.01$. ${ }^{* * *} p<0.001$.

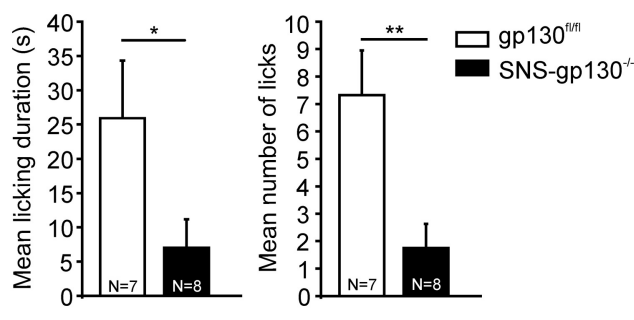

Figure 8. Attenuated CA-induced nocifensive behavior in SNS-gp $130^{-/-}$mice. SNSgp $130^{-/-}$mice displayed a significantly shorter licking duration and reduced number of licks of their hindpaws in response to an injection of $20 \mu \mathrm{l}$ 1\% CA during the 5 min observation period. ${ }^{*} p<0.05 .{ }^{* *} p<0.01$.
2010). Here, we present strong evidence that regulation of TRPA1 by gp 130 primarily takes place on the transcriptional level because (1) Trpal mRNA expression was reduced in SNS$g p 130^{-/-}$compared with control mice (Figs. 2 and 3); (2) the percentage of Trpal mRNA-expressing neurons was lower in SNS- $g p 130^{-/-}$than in control mice (Figs. 4 and 5); and (3) Trpa1 mRNA expression was significantly downregulated by experimental inhibition of the JAK-STAT pathway (Fig. 6).

Regulation of TRPA1 so far has been predominantly studied on the level of ion-channel modification (for review, see Nilius et al., 2012); however, only a few factors are known to influence Trpal mRNA expression. The proinflammatory cytokines TNF- $\alpha$ and IL- 1 activate the transcription factors NF- $\kappa$ B and HIF-1a, which increase Trpal mRNA expression (Hatano et al., 2012). Further support for a cytokine-based regulation of Trpa1 comes from a transgenic IL-13 mouse model for atopic dermatitis, in which Trpal expression is increased in mast cells, DRG neurons, and nerve fibers innervating the skin (Oh et al., 2013). In DRG neurons, previous studies mainly investigated differential Trpal expression after inflammation (Obata et al., 2005; Schwartz et al., 2011; Merrill et al., 2012) and during late embryonic and postnatal development (Hjerling-Leffler et al., 2007; Abdel Samad et al., 2010; Gascon et al., 2010; Franck et al., 2011). After inflammation and spinal nerve ligation, NGF increases Trpa1 mRNA expression in DRG neurons via p38 (Obata et al., 2005; Diogenes et al., 2007). During development, the signaling receptor for GDNF family ligand Ret is required for Trpal expression and the development of nonpeptidergic DRG neurons (Luo et al., 2007; Abdel Samad et al., 2010; Franck et al., 2011). However, Ret also regulates Trpa1 expression in adulthood, and Trpa1 mRNA levels are increased by overexpression of the GDNF family ligand artemin, but not by injection of GDNF (Obata et al., 2005; Elitt et al., 2006; Franck et al., 2011).

Apart from their crucial role in inflammation and regeneration, cytokines of the IL- 6 family are important survival and differentiation factors for neurons (Murphy et al., 1991, 1993; Thompson et al., 1996; Banner et al., 1998; Nakashima et al., 1999; Zhong et al., 1999). Our results indicate a new role for IL-6-related cytokines, in which gp130 determines the expression of TRPA1, most likely via the JAK-STAT pathway. Our model of gp130-depedent ion channel expression in nociceptive neurons is backed up by studies investigating the role of OSM in DRG neurons where OSM is essential for the development of a subpopulation of TRPV1/P2X3-expressing neurons (Morikawa et al., 2004). The OSM receptor $\beta$ is predominantly expressed in nonpeptidergic neurons, and its expression starts around postnatal day 0 before it reaches adult expression levels at P14 (Tamura et al., 2003; Morikawa et al., 2004). OSM ${ }^{-1-}$ mice do not only reveal attenuated reactions to the injection of TRPV1 and P2X3 agonists, but also to formalin injection and in the tail-clip test for mechanical sensitivity. Because formalin is a direct agonist for the mechanosensitive channel TRPA1 (McNamara et al., 2007), this test can also be interpreted as an indicator for a differential expression of TRPA1 in $O S M^{-/-}$mice, which so far has not been investigated. In line with these results, we observed that gp130 was especially necessary for Trpal expression in nonpeptidergic IB4-binding neurons (Fig. 5) and that the ablation of gp130 affected Trpal expression already during early postnatal development (Fig. 3). In contrast to the study of Morikawa et al. (2004), we detected neither a change in Trpv1 mRNA expression levels (Fig. 3) nor in the percentage of TRPV1-expressing neurons in SNS-gp130 $10^{-1-}$ mice (Fig. 7). This difference can easily be explained by the nature of the two mouse strains. In SNS-gp130 
mice, gp130 ablation is effective in $90 \%$ of the $\mathrm{Na}_{\mathrm{v}} 1.8$-expressing DRG neuron population (Andratsch et al., 2009). Hence, a residual population of nociceptive neurons still maintains gp130 signaling. Furthermore, functional TRPV1 expression emerges on embryonic day E12.5 and thus precedes $\mathrm{Na}_{\mathrm{v}} 1.8$ and Crerecombinase expression, which becomes detectable around $\mathrm{P} 0$ and coincides with TRPA1 expression (Agarwal et al., 2004; Hjerling-Leffler et al., 2007). However, in $O S M^{-1-}$ mice with a global null mutation of OSM, it cannot be excluded that nonneuronal cell types contribute to the phenotype observed. More importantly, OSM effects can be conveyed via both OSMR- $\beta$ gp130 and LIFR-gp130 heteromeric receptor complexes. The latter can regulate specific populations of sensory neurons during embryonic development (Murphy et al., 1997), whereas TRPV1expressing populations are very likely established before gp 130 depletion in SNS-gp130-/- mice.

Although different mechanisms, including mechanically activated ion channels, have been proposed for force transduction in nociceptive neurons, the molecular mechanisms of mechanonociception are still largely enigmatic (Lumpkin and Caterina, 2007; Delmas et al., 2011; Delmas and Coste, 2013). We have previously shown that cultured SNS-gp130-/- DRG neurons demonstrate reduced excitability compared with control mice, which is based on increased delayed rectifier and A-type potassium currents with no observable changes in voltage-gated sodium and calcium currents. Moreover, this is accompanied by increased expression of A-type channel Kcna4, but not Kcnh1 (Langeslag et al., 2014). Although Kcna4 has not been associated with mechanonociception, reduced excitability of nociceptive fibers could lead to a hyponociceptive phenotype. However, our previous studies do not reveal reduced sensitivity of $S N S-g p 130^{-/-}$mice to heat stimulation under basal conditions (Andratsch et al., 2009; Langeslag et al., 2011). Therefore, the reduced excitability would have to be restricted to mechanosensitive $\mathrm{C}$-fibers, a theory for which we do not have any indication. Alternatively to a reduced neuronal excitability, we present here with the decreased expression of TRPA1 a further possible mechanism for the deficit in mechanonociception of SNS- $g p 130^{-/-}$mice. Among several other candidate ion channels, TRPA1 has evolved as an important transducer for noxious mechanical stimuli. TRPA1 can be activated by mechanical stimulation of DRG neurons, and a null mutation of TRPA1 affects intermediate or slowly adapting mechanosensitive ionic currents in small-diameter DRG neurons (Vilceanu and Stucky, 2010; Brierley et al., 2011). Furthermore, this effect can be rescued by reintroduction of TRPA1 into DRG neurons of TRPA1 knock-out mice (Brierley et al., 2011). Although controversial results have been published, the majority of studies show that deletion and pharmacological inhibition of TRPA1 reduce the responsiveness of nociceptors to mechanical forces in electrophysiological recordings of single-nerve fibers and in assays of mechanosensitivity in vivo (Bautista et al., 2006; Kwan et al., 2006, 2009; Petrus et al., 2007). The reduced mechanosensitivity of SNS-gp130 ${ }^{-/-}$mice in the present study bears great resemblance to the previously published phenotype observed in TRPA1 ${ }^{-1-}$ mice. In particular, both transgenic mouse strains reveal deficits in the detection of strong mechanical forces (Kwan et al., 2006).

Together, we propose a model in which the presence of gp 130 in small DRG neurons is critically important for mechanonociception and control of TRPA1 expression in nonpeptidergic neurons. Our data shed new light on the importance of IL-6-related cytokines for the development and functional properties of the nociceptive system. Despite conflicting results, numerous studies indicate that pharmacological inhibition of TRPA1 attenuates mechanical hypersensitivity originating from inflammation, nerve injury, or chemotherapy-induced neuropathy (Obata et al., 2005; Bautista et al., 2006; Dai et al., 2007; Petrus et al., 2007; Eid et al., 2008; Brierley et al., 2011; Nassini et al., 2011). Neuropoietic IL-6 is a key mediator in innate immunity, inflammation, and mechanical hypersensitivity in different models for chronic pain (Brenn et al., 2007; Quarta et al., 2011). The present study stresses the importance of the IL-6 signal transducer gp130 in nociceptor responsiveness. Rather than gp130 causing direct sensitization, we suggest that it acts in nociceptors as general switch for the expression of TRPA1, as one critically important ion channel for mechanonociception.

\section{References}

Abdel Samad O, Liu Y, Yang FC, Kramer I, Arber S, Ma Q (2010) Characterization of two Runxl-dependent nociceptor differentiation programs necessary for inflammatory versus neuropathic pain. Mol Pain 6:45. CrossRef Medline

Agarwal N, Offermanns S, Kuner R (2004) Conditional gene deletion in primary nociceptive neurons of trigeminal ganglia and dorsal root ganglia. Genesis 38:122-129. CrossRef Medline

Andratsch M, Mair N, Constantin CE, Scherbakov N, Benetti C, Quarta S, Vogl C, Sailer CA, Uceyler N, Brockhaus J, Martini R, Sommer C, Zeilhofer HU, Müller W, Kuner R, Davis JB, Rose-John S, Kress M (2009) A key role for gp130 expressed on peripheral sensory nerves in pathological pain. J Neurosci 29:13473-13483. CrossRef Medline

Bandell M, Story GM, Hwang SW, Viswanath V, Eid SR, Petrus MJ, Earley TJ, Patapoutian A (2004) Noxious cold ion channel TRPAl is activated by pungent compounds and bradykinin. Neuron 41:849-857. CrossRef Medline

Banner LR, Patterson PH, Allchorne A, Poole S, Woolf CJ (1998) Leukemia inhibitory factor is an anti-inflammatory and analgesic cytokine. J Neurosci 18:5456-5462. Medline

Barabas ME, Kossyreva EA, Stucky CL (2012) TRPA1 is functionally expressed primarily by IB4-binding, non-peptidergic mouse and rat sensory neurons. PLoS One 7:e47988. CrossRef Medline

Bauer S, Kerr BJ, Patterson PH (2007) The neuropoietic cytokine family in development, plasticity, disease and injury. Nat Rev Neurosci 8:221-232. CrossRef Medline

Bautista DM, Movahed P, Hinman A, Axelsson HE, Sterner O, Högestätt ED, Julius D, Jordt SE, Zygmunt PM (2005) Pungent products from garlic activate the sensory ion channel TRPA1. Proc Natl Acad Sci U S A 102: 12248-12252. CrossRef Medline

Bautista DM, Jordt SE, Nikai T, Tsuruda PR, Read AJ, Poblete J, Yamoah EN, Basbaum AI, Julius D (2006) TRPAl mediates the inflammatory actions of environmental irritants and proalgesic agents. Cell 124:1269-1282. CrossRef Medline

Benjamini Y, Hochberg Y (1995) Controlling the false discovery rate: a practical and powerful approach to multiple testing. J R Stat Soc Ser B 57:289-300.

Brenn D, Richter F, Schaible HG (2007) Sensitization of unmyelinated sensory fibers of the joint nerve to mechanical stimuli by interleukin- 6 in the rat: an inflammatory mechanism of joint pain. Arthritis Rheum 56:351359. CrossRef Medline

Brierley SM, Castro J, Harrington AM, Hughes PA, Page AJ, Rychkov GY, Blackshaw LA (2011) TRPA1 contributes to specific mechanically activated currents and sensory neuron mechanical hypersensitivity. J Physiol 589:3575-3593. CrossRef Medline

Camprubí-Robles M, Mair N, Andratsch M, Benetti C, Beroukas D, Rukwied R, Langeslag M, Proia RL, Schmelz M, Ferrer Montiel AV, Haberberger RV, Kress M (2013) Sphingosine-1-phosphate-induced nociceptor excitation and ongoing pain behavior in mice and humans is largely mediated by S1P3 receptor. J Neurosci 33:2582-2592. CrossRef Medline

Caspani O, Zurborg S, Labuz D, Heppenstall PA (2009) The contribution of TRPM8 and TRPA1 channels to cold allodynia and neuropathic pain. PLoS One 4:e7383. CrossRef Medline

Dai Y, Wang S, Tominaga M, Yamamoto S, Fukuoka T, Higashi T, Kobayashi K, Obata K, Yamanaka H, Noguchi K (2007) Sensitization of TRPA1 by 
PAR2 contributes to the sensation of inflammatory pain. J Clin Invest 117:1979-1987. CrossRef Medline

Delmas P, Coste B (2013) Mechano-gated ion channels in sensory systems. Cell 155:278-284. CrossRef Medline

Delmas P, Hao J, Rodat-Despoix L (2011) Molecular mechanisms of mechanotransduction in mammalian sensory neurons. Nat Rev Neurosci 12:139-153. CrossRef Medline

Diogenes A, Akopian AN, Hargreaves KM (2007) NGF up-regulates TRPA1: implications for orofacial pain. J Dent Res 86:550-555.

Dittert I, Vlachová V, Knotková H, Vitásková Z, Vyklicky L, Kress M, Reeh PW (1998) A technique for fast application of heated solutions of different composition to cultured neurones. J Neurosci Methods 82:195-201. CrossRef Medline

Dubin AE, Patapoutian A (2010) Nociceptors: the sensors of the pain pathway. J Clin Invest 120:3760-3772. CrossRef Medline

Eid SR, Crown ED, Moore EL, Liang HA, Choong KC, Dima S, Henze DA, Kane S, Urban MO (2008) HC-030031, a TRPAl selective antagonist, attenuates inflammatory- and neuropathy-induced mechanical hypersensitivity. Mol Pain 4:48. CrossRef Medline

Elitt CM, McIlwrath SL, Lawson JJ, Malin SA, Molliver DC, Cornuet PK, Koerber HR, Davis BM, Albers KM (2006) Artemin overexpression in skin enhances expression of TRPV1 and TRPA1 in cutaneous sensory neurons and leads to behavioral sensitivity to heat and cold. J Neurosci 26:8578-8587. CrossRef Medline

Franck MC, Stenqvist A, Li L, Hao J, Usoskin D, Xu X, Wiesenfeld-Hallin Z, Ernfors P (2011) Essential role of Ret for defining non-peptidergic nociceptor phenotypes and functions in the adult mouse. Eur J Neurosci 33:1385-1400. CrossRef Medline

Gascon E, Gaillard S, Malapert P, Liu Y, Rodat-Despoix L, Samokhvalov IM, Delmas P, Helmbacher F, Maina F, Moqrich A (2010) Hepatocyte growth factor-Met signaling is required for Runx1 extinction and peptidergic differentiation in primary nociceptive neurons. J Neurosci 30: 12414-12423. CrossRef Medline

Hatano N, Itoh Y, Suzuki H, Muraki Y, Hayashi H, Onozaki K, Wood IC, Beech DJ, Muraki K (2012) Hypoxia-inducible factor-1 $\alpha$ (HIF1 $\alpha$ ) switches on transient receptor potential ankyrin repeat 1 (TRPA1) gene expression via a hypoxia response element-like motif to modulate cytokine release. J Biol Chem 287:31962-31972. CrossRef Medline

Heinrich PC, Behrmann I, Haan S, Hermanns HM, Müller-Newen G, Schaper F (2003) Principles of interleukin (IL)-6-type cytokine signalling and its regulation. Biochem J 374:1-20. CrossRef Medline

Hjerling-Leffler J, Alqatari M, Ernfors P, Koltzenburg M (2007) Emergence of functional sensory subtypes as defined by transient receptor potential channel expression. J Neurosci 27:2435-2443. CrossRef Medline

Jordt SE, Bautista DM, Chuang HH, McKemy DD, Zygmunt PM, Högestätt ED, Meng ID, Julius D (2004) Mustard oils and cannabinoids excite sensory nerve fibres through the TRP channel ANKTM1. Nature 427: 260-265. CrossRef Medline

Kim YS, Son JY, Kim TH, Paik SK, Dai Y, Noguchi K, Ahn DK, Bae YC (2010) Expression of transient receptor potential ankyrin 1 (TRPA1) in the rat trigeminal sensory afferents and spinal dorsal horn. J Comp Neurol 518: 687-698. CrossRef Medline

Kwan KY, Allchorne AJ, Vollrath MA, Christensen AP, Zhang DS, Woolf CJ, Corey DP (2006) TRPAl contributes to cold, mechanical, and chemical nociception but is not essential for hair-cell transduction. Neuron 50: 277-289. CrossRef Medline

Kwan KY, Glazer JM, Corey DP, Rice FL, Stucky CL (2009) TRPA1 modulates mechanotransduction in cutaneous sensory neurons. J Neurosci 29: 4808-4819. CrossRef Medline

Langeslag M, Constantin CE, Andratsch M, Quarta S, Mair N, Kress M (2011) Oncostatin M induces heat hypersensitivity by gp130-dependent sensitization of TRPV1 in sensory neurons. Mol Pain 7:102. CrossRef Medline

Langeslag M, Malsch P, Welling A, Kress M (2014) Reduced excitability of gp130-deficient nociceptors is associated with increased voltage-gated potassium currents and Kcna4 channel upregulation. Pflugers Arch. Advance online publication. Retrieved Jan. 25, 2014. doi: 10.1007/s00424014-1443-0. CrossRef Medline

Liu K, Samuel M, Ho M, Harrison RK, Paslay JW (2010) NPPB structurespecifically activates TRPAl channels. Biochem Pharmacol 80:113-121. CrossRef Medline

Loy B, Apostolova G, Dorn R, McGuire VA, Arthur JS, Dechant G (2011)
P38A and P38B mitogen-activated protein kinases determine cholinergic transdifferentiation of sympathetic neurons. J Neurosci 31:12059-12067. CrossRef Medline

Lumpkin EA, Caterina MJ (2007) Mechanisms of sensory transduction in the skin. Nature 445:858-865. CrossRef Medline

Luo W, Wickramasinghe SR, Savitt JM, Griffin JW, Dawson TM, Ginty DD (2007) A hierarchical NGF signaling cascade controls Ret-dependent and Ret-independent events during development of nonpeptidergic DRG neurons. Neuron 54:739-754. CrossRef Medline

Macpherson LJ, Dubin AE, Evans MJ, Marr F, Schultz PG, Cravatt BF, Patapoutian A (2007) Noxious compounds activate TRPA1 ion channels through covalent modification of cysteines. Nature 445:541-545. CrossRef Medline

McNamara CR, Mandel-Brehm J, Bautista DM, Siemens J, Deranian KL, Zhao M, Hayward NJ, Chong JA, Julius D, Moran MM, Fanger CM (2007) TRPA1 mediates formalin-induced pain. Proc Natl Acad Sci U S A 104:13525-13530. CrossRef Medline

Melemedjian OK, Asiedu MN, Tillu DV, Peebles KA, Yan J, Ertz N, Dussor GO, Price TJ (2010) IL-6- and NGF-induced rapid control of protein synthesis and nociceptive plasticity via convergent signaling to the eIF4F complex. J Neurosci 30:15113-15123. CrossRef Medline

Merrill L, Girard BM, May V, Vizzard MA (2012) Transcriptional and translational plasticity in rodent urinary bladder TRP channels with urinary bladder inflammation, bladder dysfunction, or postnatal maturation. J Mol Neurosci 48:744-756. CrossRef Medline

Morikawa Y, Tamura S, Minehata K, Donovan PJ, Miyajima A, Senba E (2004) Essential function of oncostatin $\mathrm{m}$ in nociceptive neurons of dorsal root ganglia. J Neurosci 24:1941-1947. CrossRef Medline

Murphy M, Reid K, Hilton DJ, Bartlett PF (1991) Generation of sensory neurons is stimulated by leukemia inhibitory factor. Proc Natl Acad Sci U S A 88:3498-3501. CrossRef Medline

Murphy M, Reid K, Brown MA, Bartlett PF (1993) Involvement of leukemia inhibitory factor and nerve growth factor in the development of dorsal root ganglion neurons. Development 117:1173-1182. Medline

Murphy M, Dutton R, Koblar S, Cheema S, Bartlett P (1997) Cytokines which signal through the LIF receptor and their actions in the nervous system. Prog Neurobiol 52:355-378. CrossRef Medline

Nakashima K, Wiese S, Yanagisawa M, Arakawa H, Kimura N, Hisatsune T, Yoshida K, Kishimoto T, Sendtner M, Taga T (1999) Developmental requirement of gp130 signaling in neuronal survival and astrocyte differentiation. J Neurosci 19:5429-5434. Medline

Nassini R, Gees M, Harrison S, De Siena G, Materazzi S, Moretto N, Failli P, Preti D, Marchetti N, Cavazzini A, Mancini F, Pedretti P, Nilius B, Patacchini R, Geppetti P (2011) Oxaliplatin elicits mechanical and cold allodynia in rodents via TRPA1 receptor stimulation. Pain 152:1621-1631. CrossRef Medline

Nilius B, Appendino G, Owsianik G (2012) The transient receptor potential channel TRPA1: from gene to pathophysiology. Pflugers Arch 464:425458. CrossRef Medline

Obata K, Katsura H, Mizushima T, Yamanaka H, Kobayashi K, Dai Y, Fukuoka T, Tokunaga A, Tominaga M, Noguchi K (2005) TRPA1 induced in sensory neurons contributes to cold hyperalgesia after inflammation and nerve injury. J Clin Invest 115:2393-2401. CrossRef Medline

Obreja O, Schmelz M, Poole S, Kress M (2002) Interleukin-6 in combination with its soluble IL-6 receptor sensitises rat skin nociceptors to heat, in vivo. Pain 96:57-62. CrossRef Medline

Obreja O, Biasio W, Andratsch M, Lips KS, Rathee PK, Ludwig A, Rose-John S, Kress M (2005) Fast modulation of heat-activated ionic current by proinflammatory interleukin 6 in rat sensory neurons. Brain 128:16341641. CrossRef Medline

Oh MH, Oh SY, Lu J, Lou H, Myers AC, Zhu Z, Zheng T (2013) TRPA1dependent pruritus in IL-13-induced chronic atopic dermatitis. J Immunol 191:5371-5382. CrossRef Medline

Pellegrino MJ, Habecker BA (2013) STAT3 integrates cytokine and neurotrophin signals to promote sympathetic axon regeneration. Mol Cell Neurosci 56:272-282. CrossRef Medline

Petrus M, Peier AM, Bandell M, Hwang SW, Huynh T, Olney N, Jegla T, Patapoutian A (2007) A role of TRPA1 in mechanical hyperalgesia is revealed by pharmacological inhibition. Mol Pain 3:40. CrossRef Medline

Quarta S, Vogl C, Constantin CE, Üçeyler N, Sommer C, Kress M (2011) Genetic evidence for an essential role of neuronally expressed IL-6 signal transducer gp130 in the induction and maintenance of experimentally 
induced mechanical hypersensitivity in vivo and in vitro. Mol Pain 7:73. CrossRef Medline

Schneider CA, Rasband WS, Eliceiri KW (2012) NIH Image to ImageJ: 25 years of image analysis. Nat Methods 9:671-675. CrossRef Medline

Schwartz ES, Christianson JA, Chen X, La JH, Davis BM, Albers KM, Gebhart GF (2011) Synergistic role of TRPV1 and TRPA1 in pancreatic pain and inflammation. Gastroenterology 140:1283-1291.e1-2. CrossRef Medline

Story GM, Peier AM, Reeve AJ, Eid SR, Mosbacher J, Hricik TR, Earley TJ, Hergarden AC, Andersson DA, Hwang SW, McIntyre P, Jegla T, Bevan S, Patapoutian A (2003) ANKTM1, a TRP-like channel expressed in nociceptive neurons, is activated by cold temperatures. Cell 112:819-829. CrossRef Medline
Tamura S, Morikawa Y, Miyajima A, Senba E (2003) Expression of oncostatin $\mathrm{M}$ receptor beta in a specific subset of nociceptive sensory neurons. Eur J Neurosci 17:2287-2298. CrossRef Medline

Thompson SW, Dray A, Urban L (1996) Leukemia inhibitory factor induces mechanical allodynia but not thermal hyperalgesia in the juvenile rat. Neuroscience 71:1091-1094. CrossRef Medline

Vilceanu D, Stucky CL (2010) TRPA1 mediates mechanical currents in the plasma membrane of mouse sensory neurons. PLoS One 5:e12177. CrossRef Medline

Zhong J, Dietzel ID, Wahle P, Kopf M, Heumann R (1999) Sensory impairments and delayed regeneration of sensory axons in interleukin-6deficient mice. J Neurosci 19:4305-4313. Medline 